University of Nebraska - Lincoln

DigitalCommons@University of Nebraska - Lincoln

US Army Corps of Engineers

U.S. Department of Defense

2004

RDX biodegradation column study: comparison of electron donors for biologically induced reductive transformation in groundwater

Jeffrey L. Davis

US Army Engineer Research and Development Center

AltafH. Wani

Applied Research Associates, Inc., altaf.h.wani@erdc.usace.army.mil

Brenda R. O’Neal

Applied Research Associates, Inc.

Lance D. Hansen

US Army Engineer Research and Development Center

Follow this and additional works at: http://digitalcommons.unl.edu/usarmyceomaha

Davis, Jeffrey L.; Wani, Altaf H.; O’Neal, Brenda R.; and Hansen, Lance D., "RDX biodegradation column study: comparison of electron donors for biologically induced reductive transformation in groundwater" (2004). US Army Corps of Engineers. 148. http://digitalcommons.unl.edu/usarmyceomaha/148

This Article is brought to you for free and open access by the U.S. Department of Defense at DigitalCommons@University of Nebraska - Lincoln. It has been accepted for inclusion in US Army Corps of Engineers by an authorized administrator of DigitalCommons@University of Nebraska - Lincoln. 


\title{
RDX biodegradation column study: comparison of electron donors for biologically induced reductive transformation in groundwater
}

\author{
Jeffrey L. Davis ${ }^{\text {a }}$, Altaf H. Wani ${ }^{\text {b, } *}$, Brenda R. O’Neal ${ }^{\text {b }}$, Lance D. Hansen ${ }^{\text {a }}$ \\ a Environmental Laboratory, US Army Engineer Research and Development Center (Attn: CEERD-EP-E), \\ 3909 Halls Ferry Road, Vicksburg, MS 39180, USA \\ b Applied Research Associates, Inc., Southern Division, 119 Monument Place, Vicksburg, MS 39180, USA
}

Received 2 July 2003; received in revised form 20 January 2004; accepted 15 March 2004

Available online 7 June 2004

\begin{abstract}
A series of column studies, using site-specific soil and groundwater, were conducted to determine the feasibility of biologically active zone enhancement (BAZE) process for reductive biotransformation of hexahydro-1,3,5-trinitro-1,3,5-triazine (RDX) in groundwater. This treatability study examined the use of four amendments (acetate, ethanol, soluble starch, and acetate plus ammonium), which served as electron donors. Triplicate columns, with groundwater residence time of about $27.5 \mathrm{~h}$, were used for each amendment treatment and the amendment control. In treatment columns amendment dosing was $500 \mathrm{mg} / \mathrm{L} \mathrm{C}$ for carbon sources and $100 \mathrm{mg} / \mathrm{L} \mathrm{N}$ for ammonium. Each of the amendment treatments reduced RDX inlet concentrations of $100 \mu \mathrm{g} / \mathrm{L}$ to less than $1 \mu \mathrm{g} / \mathrm{L}$. The highest first-order RDX biodegradation rate ranged between 0.140 and $0.447 \mathrm{~h}^{-1}$ for acetate amended columns as compared to 0.037 to $0.083 \mathrm{~h}^{-1}$ in control columns (no amendment). The addition of soluble starch resulted in increased toxicity (based on Microtox ${ }^{\circledR}$ analysis) that was partially removed by biological activity in the columns. Ethanol addition itself did not result in increased toxicity but biological activity in this system did induce Microtox ${ }^{\circledR}$ toxicity. Acetate did not have any Microtox ${ }^{\circledR}$ toxicity associated with it. The addition of ammonium as a nitrogen source did not significantly increase the removal rate of RDX. Based on these observations acetate was selected for the field demonstration.
\end{abstract}

Published by Elsevier B.V.

Keywords: Explosives; RDX; Groundwater; Anaerobic biodegradation; Carbon source; Electron donor

\section{Introduction}

Explosive nitroaromatic compounds in soil and groundwater present a significant cleanup challenge at many active and formerly used military facilities. These energetic compounds have entered the environment from sites where they were manufactured, stored, disposed, or used in military training. Presently, soil and groundwater contamination by explosives (2,4,6-trinitrotoluene (TNT), hexahydro1,3,5-trinitro-1,3,5-triazine (RDX), and octahydro-1,3,5,7tetranitro-tetrazocine (HMX)) is a worldwide problem that started following intensive military activities in World War I [1]. However, in the United States the contamination of

* Corresponding author. Present address: Environmental Laboratory, US Army Engineer Research and Development Center (Attn: CEERD-EP-E), 3909 Halls Ferry Road, Vicksburg, MS 39180, USA. Tel.: +1-601-634-4820; fax: +1-601-634-4844.

E-mail address: altaf.h.wani@erdc.usace.army.mil (A.H. Wani). soil and groundwater is attributed to World War II and the Korean conflict [2]. The US Army currently has 583 sites with confirmed explosives-contaminated groundwater at 82 installations nationwide. At 22 other installations, 88 additional sites are suspected of groundwater contamination with explosives and organics [3].

RDX is a cyclic nitramine explosive that has contaminated groundwater, soil and surface water at military installations throughout the United States. RDX is of particular environmental concern because it is generally resistant to microbial transformation in aerobic environments [4] and is readily leachable $\left(K_{\mathrm{d}}=0.83-0.95 \mathrm{~L} / \mathrm{kg}\right)$ [5,6]. Ingestion of RDX adversely affects the central nervous system, gastro-intestinal tract and kidneys. RDX has also been associated with systemic poisoning usually affecting bone marrow and the liver [7]. The US Environmental Protection Agency (EPA) has established drinking water health advisory of $2 \mu \mathrm{g} / \mathrm{L}$ for exposure to RDX [8]. 

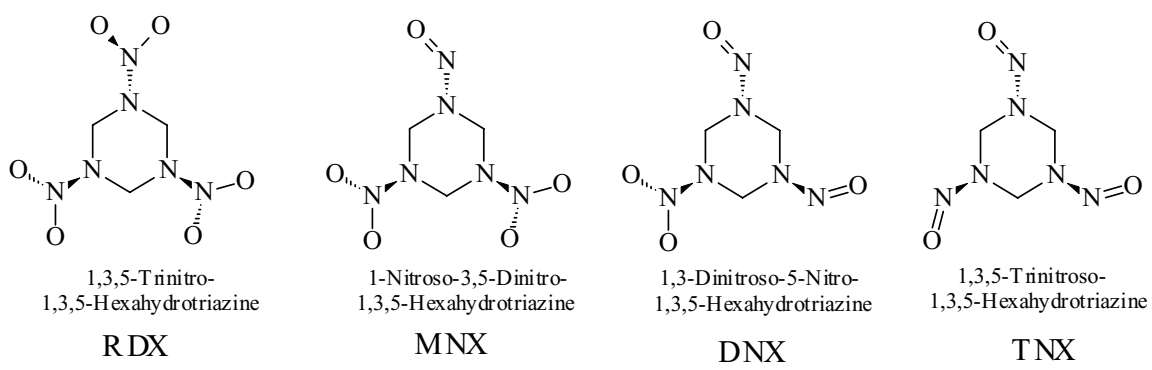

Fig. 1. Structure of RDX and its anaerobic degradation metabolites MNX, DNX, and TNX.

Biodegradation of RDX is often attributed to cometabolism in the presence of a primary carbon source under various electron acceptor conditions. Although aerobic bacterial [9-11] and fungal [12-14] metabolism of RDX has been observed, anaerobic metabolism has been reported more frequently [4,15-21]. Anaerobic biotransformation of RDX has been proven to be more favorable when aerobic and anaerobic incubation were directly compared [4,20-22]. Laboratory studies have established that hexahydro-1nitroso-3,5-dinitro-1,3,5-triazine (MNX), hexahydro-1,3dinitroso-5-nitro-1,3,5-triazine (DNX), and hexahydro-1,3, 5-trinitroso-1,3,5-triazine (TNX) (Fig. 1) are the transient biotransformation intermediates under anaerobic conditions [4,15,16,19-21]. Some researchers have proposed other metabolic intermediates, such as methylenedinitramine (MDNA), bis(hydroxy-methyl)nitramine, hydrazine, 1,1dimethyl- and 1,2-dimethylhydrazine, formaldehyde, methanol, and nitrous oxide, either as a result of direct hydrolytic ring cleavage or further breakdown of nitroso-transformation products $[4,17,23,24]$. Many of these nitroso-substituted and other nonvolatile intermediates are genotoxic carcinogens [25]. Therefore, the ideal biologically mediated RDX degradation process should result in further breakdown of these nitroso- and non-nitroso-substituted intermediates to reach an acceptable environmental end point.

Various types of readily available carbon sources (electron donors) have been used to establish anaerobic conditions in soil and groundwater cultures for reductive biotransformation of RDX. Some studies of anaerobic RDX biodegradation have used complex culture media such as nutrient broth or yeast extract, which contains multiple potential electron donors and acceptors. Previous researchers have shown that in addition to carbon source, ammonium amendment enhanced the anaerobic biodegradation of TNT and the removal rates increased with increasing amounts of ammonium until $25 \mathrm{mM}$ ammonium chloride [26]. However, the results with RDX biodegradation are somewhat conflicting. Coleman et al. [10] reported that the presence of ammonium delayed onset and reduced amount of RDX biodegradation because of preferential use of ammonium as $\mathrm{N}$ source, while Beller [16] reported that ammonium had no discernible effects on reductive biotransformation of RDX.

Although many laboratory-scale studies have established that RDX can be biodegraded, the experimental conditions in these studies were not designed to be directly relevant to the field in situ environment. This study addresses the fate of RDX under biologically induced reductive conditions using site-specific aquifer material and groundwater. The study evaluated the potential of indigenous mixed cultures existing in the aquifer material to biodegrade RDX in groundwater in presence of three different carbon sources: acetate, ethanol, and soluble starch. The study also delineated the effects of ammonium on reductive biotransformation of RDX.

\section{Materials and methods}

\subsection{Soil and groundwater}

Aquifer material and groundwater samples were collected from the former Nebraska Ordinance Plant (NOP) about $2.4 \mathrm{~km}$ (1.5 mile) south of Mead, NE, USA. Soil and groundwater samples were collected from a depth of

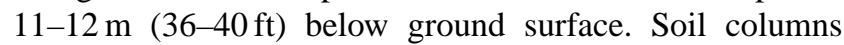
were collected in $5 \mathrm{~cm}(2 \mathrm{in}$.) diameter acetate liners, by the direct-push method using a track-mounted mobile sampling device. The soil columns were thoroughly sealed at both ends to prevent loss of water from the aquifer material during storage and shipping. Groundwater was collected from the monitoring well using a submersible pump. After removing three well volumes, groundwater was collected in $201 \mathrm{~L}$ (55 gal) drums. Samples of aquifer material and groundwater were shipped to US Army Engineer Research and Development Center (ERDC), Vicksburg, MS, USA via a refrigerated truck.

\subsection{Experimental}

Five sets of triplicate columns (Fig. 2) were used to evaluate four different amendments (carbon sources), leaving the remaining one as control with no amendment. The polyvinyl chloride (PVC) columns were $104 \mathrm{~cm}(3.4 \mathrm{ft})$ in length with an inside diameter of $3.8 \mathrm{~cm}$ (1.5 in.). Aquifer material from the acetate liners was slowly emptied into the PVC columns to create minimally disturbed soil cores. Both ends of the columns were closed with PVC caps screened with porous $(100 \mu \mathrm{m})$ PVC. Additional sampling ports were placed along the length of each column to allow 


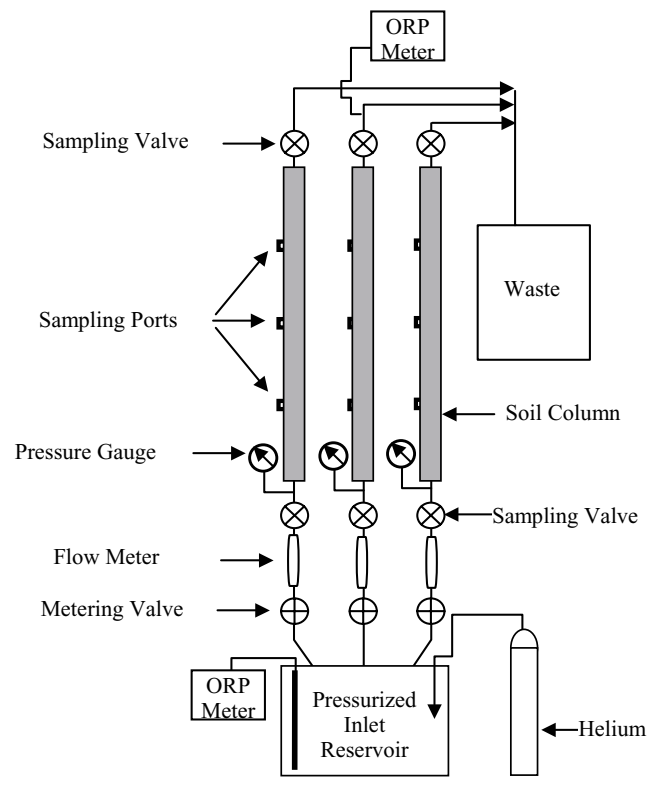

Fig. 2. Schematics of experimental column system.

for intermediate sampling and development of contaminant bed profiles. Three intermediate sampling ports located at an interval of $26 \mathrm{~cm}$ (10.4 in.) divided the entire soil core in each column into four equal sections. These intermediate sampling ports were fitted with $3 \mathrm{~mm}$ (1/8 in.) adapters and tubing clamps. Pressure gauges were installed at the inlet to each individual column, to examine the effects of microbial growth (biofouling) on groundwater flow, backpressure, and the hydrodynamic properties of the aquifer material. The middle column in each triplicate set was equipped with an oxidation-reduction potential (ORP) electrode via a flowthrough cell to compare the reduced conditions in the effluent stream to that of the inlet reservoir. Groundwater amended with different carbon sources (electron donors) was forced through the columns by pressurizing the inlet reservoirs with helium gas. A metering valve controlled the flow of pressurized groundwater through triplicate columns in parallel.

\subsection{Operation}

The initial concentration of RDX in groundwater from the former NOP site was about $66 \mu \mathrm{g} / \mathrm{L}$. However, because of unknown reasons RDX was degraded in the drums during storage. The groundwater in the inlet reservoirs was spiked with RDX stock solution to make the final RDX concentration of $100 \mu \mathrm{g} / \mathrm{L}$ in feed water. Three different carbon sources (acetate, ethanol, and soluble starch) were tested for their potential to achieve reduced conditions for reductive biotransformation of RDX. In addition to these carbon sources, ammonium was also used to evaluate the effects of ammonium on RDX biodegradation. The operating conditions are summarized in Table 1. For each amendment the triplicate columns were operated in parallel with a common feed. Groundwater samples were collected from inlet and outlet sampling ports weekly. Samples from intermediate ports along the column length were collected twice during the study for bed profile determination. Samples were stored at $4{ }^{\circ} \mathrm{C}$ until extraction for RDX and amendment analysis.

\subsection{Analytical techniques}

Acetate and other common ionizable groundwater constituents (chloride, carbonate, sulfate, and nitrate) analyses were performed using a DIONEX ion chromatograph (IC). Chemical separation and detection was achieved using an Ionpac AS11 analytical column $(4 \mathrm{~mm} \times 250 \mathrm{~mm})$ and a Dionex conductivity detector (1.25 $\mu \mathrm{L}$ internal volume). The mobile phase consisted of $\mathrm{NaOH}$, flowing at $1.5 \mathrm{~mL} / \mathrm{min}$. The sample volume was $25 \mu \mathrm{L}$ of filtered sample $(0.45 \mu \mathrm{m})$.

Ammonium concentration in groundwater was measured colorimetrically using Lachat. QuickChem Method 10-10706-1-D, which has an effective linear range of $2-100 \mathrm{mg} / \mathrm{L}$ (as $\mathrm{N}$ ), was used for the analysis.

Explosives analysis in the groundwater involved preconcentrating of groundwater samples by solid phase extraction (SPE) with Waters Porapak ${ }^{\circledR}$ RDX Sep-Pak ${ }^{\circledR}$ Vac cartridges. These cartridges have an RDX recovery of $>99.5 \%$ from known concentration RDX standard samples. The adsorbed explosive compounds were then eluted from these cartridges with acetonitrile for analysis. Explosives analysis was performed using a Waters high pressure liquid chromatograph (HPLC) consisting of a 610 Fluid Unit pump, a Waters 717 plus autosampler including a $200 \mu \mathrm{L}$ loop injector, and a Waters 486 tunable UV absorbance detector. Sample absorbance was measured at $245 \mathrm{~nm}$. The injection volume was $50 \mu \mathrm{L}$. Chemical separation

Table 1

Column operating conditions

\begin{tabular}{|c|c|c|c|c|c|c|}
\hline \multirow[t]{2}{*}{ Column set } & \multirow{2}{*}{$\begin{array}{l}\text { Groundwater } \\
\text { flow }(\mathrm{mL} / \mathrm{min})\end{array}$} & \multirow{2}{*}{$\begin{array}{l}\text { RDX } \\
\text { concentration } \\
(\mu \mathrm{g} / \mathrm{L}) \\
\end{array}$} & \multicolumn{4}{|c|}{ Amendment concentration } \\
\hline & & & Acetate (mg/L C) & Ethanol (mg/L C) & Starch (mg/L C) & Ammonium (mg/L N) \\
\hline 1 & $0.2 \pm 0.05$ & $\sim 100$ & $\sim 500$ & 0 & 0 & 0 \\
\hline 2 & $0.2 \pm 0.05$ & $\sim 100$ & 0 & $\sim 500$ & 0 & 0 \\
\hline 3 & $0.2 \pm 0.05$ & $\sim 100$ & 0 & 0 & $\sim 500$ & 0 \\
\hline 4 & $0.2 \pm 0.05$ & $\sim 100$ & $\sim 500$ & 0 & 0 & $\sim 100$ \\
\hline 5 & $0.2 \pm 0.05$ & $\sim 100$ & 0 & 0 & 0 & 0 \\
\hline
\end{tabular}

Amendment concentrations are given as $\mathrm{mg} / \mathrm{L}$ carbon (nominal) for acetate, ethanol and starch, and as $\mathrm{mg} / \mathrm{L}$ nitrogen for ammonium. 
was achieved using a Supelco LC-18 reverse phase HPLC column $(25 \mathrm{~cm} \times 4.6 \mathrm{~mm}, 5 \mu \mathrm{m})$ with a Novapak C-18 pre-column for the primary column. The mobile phase consisted of 1:1 (v/v) methanol/organic-free reagent water at a flow of $1.2 \mathrm{~mL} / \mathrm{min}$. EPA Method 8330 was used for the analysis of RDX and its transformation products.

\subsection{Column hydrodynamics and RDX biodegradation kinetics}

A tracer test was performed to evaluate the hydrodynamic properties of the aquifer material in the columns. Tracer tests were performed by adding chloride at nontoxic levels and sampling the effluent periodically to develop a breakthrough curve. An advection-dispersion model was fitted to the data to determine dispersivity and the bed porosity:

$\frac{\partial C}{\partial t}=\alpha v \frac{\partial^{2} C}{\partial x^{2}}-v \frac{\partial C}{\partial x}$

where $C$ is the chloride concentration $(\mathrm{mg} / \mathrm{L}), t$ the time elapsed (h), $\alpha$ the dispersivity $(\mathrm{cm}), v=q /(A n)$ the average interstitial or pore water velocity $(\mathrm{cm} / \mathrm{h}), q$ the groundwater flow $(\mathrm{mL} / \mathrm{h}), A$ the column cross-section area $\left(\mathrm{cm}^{2}\right), n$ the aquifer material porosity, and $x$ the distance from column inlet $(\mathrm{cm})$.

Given the initial condition $C(x, 0)=C_{\mathrm{i}}$, and boundary conditions $C(0, t)=C_{0}$ and $\partial C / \partial x(\infty, t)=0$ the solution [27] to Eq. (1) is shown in Eq. (2):

$$
\begin{aligned}
C= & C_{\mathrm{i}}+\left(\frac{C_{0}-C_{\mathrm{i}}}{2}\right) \\
& \times\left[\operatorname{erfc}\left(\frac{x-v t}{2 \sqrt{\alpha v t}}\right)+\exp \left(\frac{x}{\alpha}\right) \operatorname{erfc}\left(\frac{x+v t}{2 \sqrt{\alpha v t}}\right)\right]
\end{aligned}
$$

Rate of RDX biotransformation was determined by sampling at the intermediate ports. A contaminant profile was developed and an advection-dispersion model for contaminant transport with decay was fitted to the results. The bed profile sampling was done on week 16 when the operating conditions were steady and columns had reached equilibrium conditions with steady RDX removal. The following equation was applied:

$\frac{\partial C}{\partial t}=\alpha v \frac{\partial^{2} C}{\partial x^{2}}-v \frac{\partial C}{\partial x}-k C$

where $k$ is the RDX first-order biodegradation rate coefficient $\left(\mathrm{h}^{-1}\right)$.

At steady state, with the boundary conditions $C(0, t)=$ $C_{0}$ and $\partial C / \partial x(\infty, t)=0$, Eq. (3) can be solved [27] to Eq. (4):

$C=C_{0} \exp \left[\left(\frac{x}{2 \alpha v}\right)\left(v-\sqrt{v^{2}+4 k \alpha v}\right)\right]$

The statistical analysis of first-order biodegradation rate coefficients obtained for RDX in different amendment treatments was performed using SigmaStat statistical software. One way analysis of variance for pair-wise multiple comparisons was done by using Tukey test.

\subsection{Toxicological analysis}

Toxicological assays were conducted on liquid aliquots of column influent and effluent samples. RDX cytotoxicity was evaluated using a strain of bioluminescent bacteria, Vibrio fischeri. Freeze dried V. fischeri and reagents for the bioassay were obtained from Azur Scientific (Carlsbad, CA). A proportionate quantity of salt medium was added to each aqueous RDX sample. Samples were serially diluted to evaluate the effect of sample concentration on cytotoxicity. Bacterial bioluminescence was measured following 5 and $15 \mathrm{~min}$ incubation using a Microtox ${ }^{\circledR}$ M500 analyzer (Azur Scientific, California). The results are reported as $\mathrm{EC}_{50}$ values, the effective concentration where $50 \%$ of the expected fluorescence from the test bacterium, $V$. fischeri, was inhibited. Higher $\mathrm{EC}_{50}$ values indicate lower acute toxicity.

\section{Results and discussion}

The aquifer material collected from the former NOP site was predominantly alluvial sand. The aquifer material was predominantly fine sand (94\% fines, $0.8 \%$ silt, and $0.4 \%$ clay) with very low total organic content $(0.0055 \%$, wet basis). Results of initial characterization of groundwater from the former NOP site are summarized in Fig. 3. Groundwater was neutral with relatively high levels of sulfate and nitrate. RDX concentrations were around $66 \mu \mathrm{g} / \mathrm{L}$ with low levels of TNT.

\subsection{Column hydrodynamics}

The results of tracer tests revealed that the former NOP aquifer material has an effective porosity of $0.28 \pm 0.06$ and dispersivity ranging between 0.28 and $11.6 \mathrm{~cm}$ (Fig. 4). The measured porosities are within the values expected for a sandy soil [28]. The designed groundwater flow of $0.2 \mathrm{~mL} / \mathrm{min}$ resulted in groundwater residence time of approximately $27.5 \mathrm{~h}$. The estimated hydraulic conductivity of the aquifer materials ranged between $1.2 \times 10^{-3}$ and $9.8 \times 10^{-4} \mathrm{~cm} / \mathrm{s}$, with an average value of $2.5 \times 10^{-3} \mathrm{~cm} / \mathrm{s}$.

Groundwater flow throughout the study was relatively constant $(0.2 \pm 0.05 \mathrm{~mL} / \mathrm{min})$ in all five triplicate-column sets and fluctuated slightly from the designed flow. Backpressure buildup throughout the project duration was minimal, indicating that biofouling did not occur.

A significant drop in redox potential $\left(E_{\mathrm{h}}\right)$ between inlet and outlet streams was observed in all the columns. In the acetate amended treatment, $E_{\mathrm{h}}$ dropped from initial value of $200 \mathrm{mV}$ to about $-300 \mathrm{mV}$ (Fig. 5). Similar pattern of drop in $E_{\mathrm{h}}$ was observed in other treatment columns in which ethanol, and soluble starch was used as a carbon source. Interestingly, in the control column the $E_{\mathrm{h}}$ of influent stream was lower as compared to the $E_{\mathrm{h}}$ of effluent stream (Fig. 5). These changes in the redox potential were not only as a result of presence of readily available carbon source, but partially 


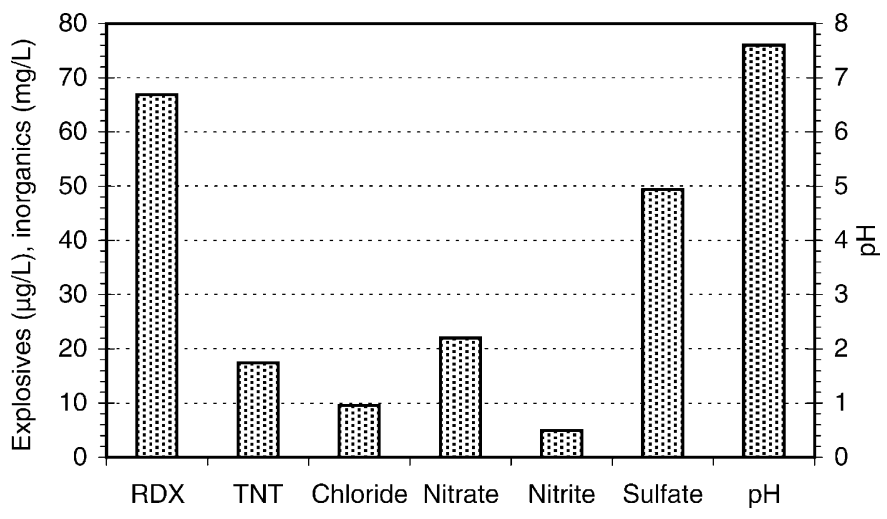

Fig. 3. Initial characteristics of NOP groundwater.
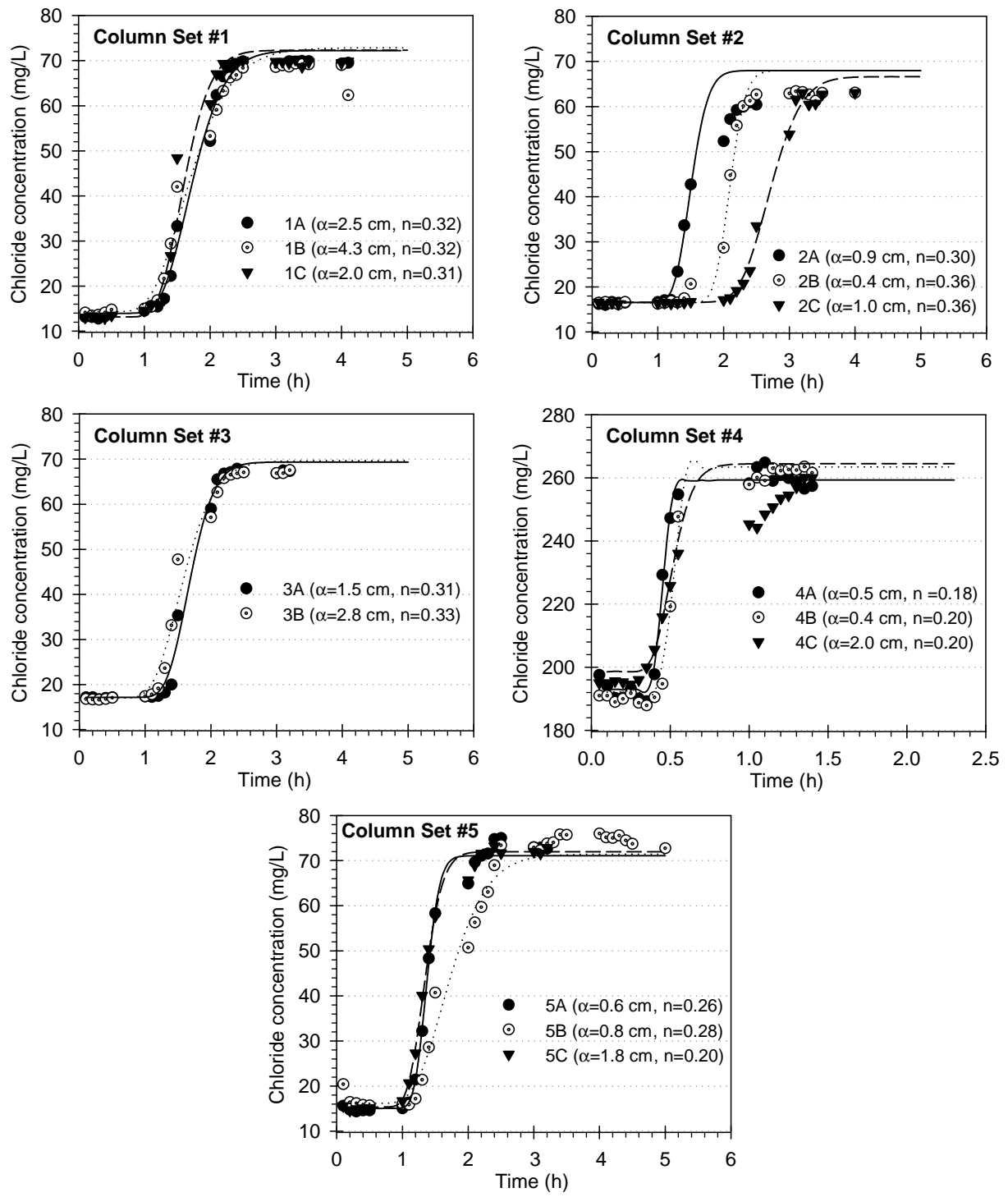

Fig. 4. Chloride tracer breakthrough curves for individual columns ( $\alpha$ : dispersivity, $n$ : aquifer material porosity). Symbols and lines represent the actual data and model fit, respectively. 

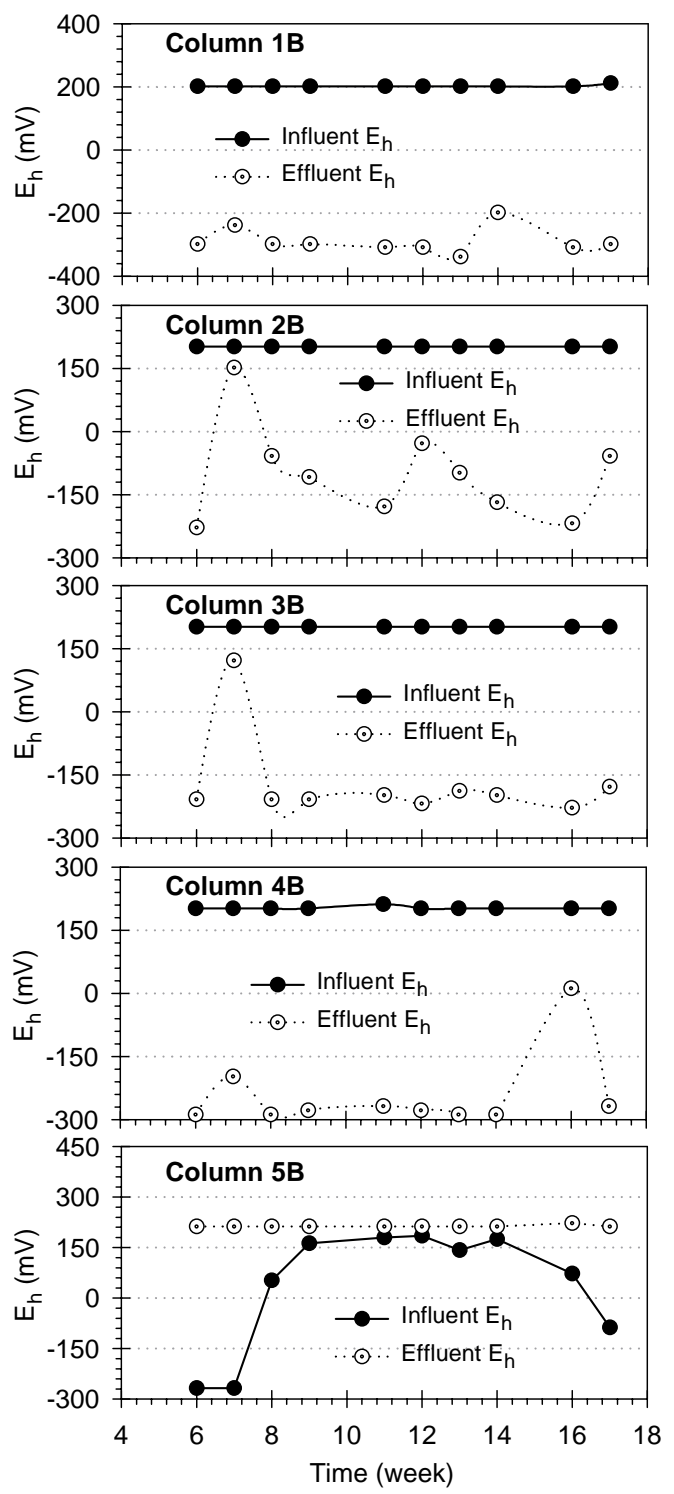

Fig. 5. Redox potential $\left(E_{\mathrm{h}}\right)$ at column inlets and outlets. In each triplicate set only middle column was equipped with ORP electrode.

were manifested by the use of helium gas for pressurizing the groundwater in the inlet reservoirs, for feeding groundwater to the individual columns, that reduced the partial pressure of oxygen in groundwater. As a result noticeable reduction in $E_{\mathrm{h}}$ was observed in inlet reservoir of the control column.

\subsection{RDX biodegradation}

RDX concentrations $(\sim 100 \mu \mathrm{g} / \mathrm{L})$ in the influent stream were remediated to below detection levels of $1 \mu \mathrm{g} / \mathrm{L}$ in each column irrespective of the type of carbon source (electron donor) used (Fig. 6). Variations in the RDX influent concentrations were the result of partial biodegradation of RDX in the inlet reservoirs because of reduced conditions created by pressurizing the groundwater with helium gas. These variations in influent RDX concentrations were more pronounced in inlet reservoir of soluble starch amended column, probably because of high population of RDX degraders (Fig. 6).

About 10-15\% of the influent acetate concentration in acetate amended column was used by the biological activity in the soil columns. The utilization of influent acetate levels was slightly higher in the columns amended with acetate and ammonium, probably because of the increased biological activity by resident microorganisms in presence of ammonium, a more favorable nitrogen source. One notable observation in the ethanol-amended columns and in the soluble starch amended columns was the partial conversion of these carbon sources to acetate under reduced environment in the inlet reservoirs as well as in soil columns. The conversion of soluble starch to acetate was more pronounced than the conversion of ethanol to acetate (Fig. 6). Similar results of conversion of ethanol to acetate by enrichment cultures degrading RDX have been reported by Adrian and Lowder [29].

During the 17-week study, RDX was completely removed from the groundwater without the detection of any nitrosotransformation products in the column effluents. Even in the amendment control columns none of the RDX or its transformation products (MNX, DNX, and TNX) were detected in the effluent stream. Although no carbon was added in the control column, the reduced conditions were artificially created by pressurizing the feed groundwater with helium gas in the inlet reservoirs. From these results, it seems the ultimate fate of RDX appears to be dependent on redox conditions. In treatment columns where redox potential was very low (approximately -250 to $-300 \mathrm{mV}$ ), RDX was transformed into nonvolatile metabolites other than MNX, DNX, and TNX. Two redox dependent degradation pathways may be present. One pathway is the sequential reduction of nitro functional groups to nitroso functionality. The rates may be faster than the resolution accorded in this column study. A second pathway may be the direct attack of the ring. This direct attack resulting in ring cleavage may be active only at low redox potentials $[4,17,23,24]$. Similar results of non-nitroso-substituted biotransformation of $\left[{ }^{14} \mathrm{C}\right] \mathrm{RDX}$ by aquifer microorganisms under anaerobic conditions have been reported by Beller [16]. The researcher reported that nonvolatile metabolites MNX, DNX, and TNX constituted $\leq 0.5 \%$ of the total RDX carbon. In another study, Oh et al. [30] reported that although MNX, DNX, and TNX were detected in microcosms amended with zerovalent iron and anaerobic sludge, these nitroso-substituted RDX intermediates never accumulated above $5 \%$ of the added RDX. These researchers tentatively identified a soluble intermediate MDNA as a result of ring cleavage. However, the formation and stability of MDNA as a biotransformation product of RDX under anaerobic conditions is not yet clear.

\subsection{RDX biodegradation kinetics}

The rate of biotransformation of RDX in soil columns was evaluated from RDX degradation profile along column 

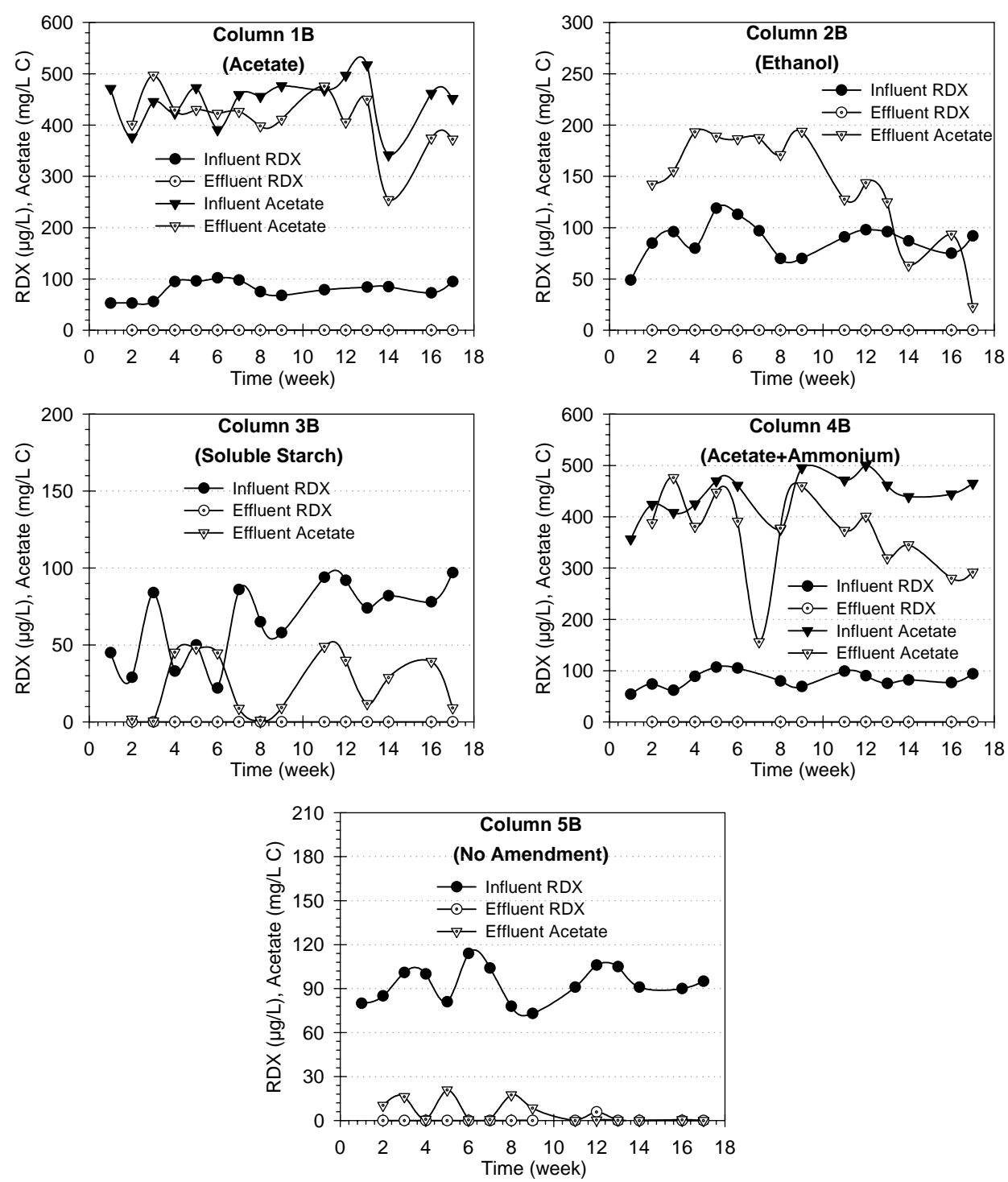

Fig. 6. RDX concentration in column influent and effluent groundwater. None of the nitroso-substituted transformation products was detected in the effluent stream.

length. Samples were collected from intermediate ports along column length on week 16 , when columns were operating at equilibrium with steady RDX removal. Fig. 7 illustrates the results of the bed profile analysis performed on week 16. Transient levels of nitroso-transformation products (MNX, DNX, and TNX) detected at intermediate sampling ports in acetate amended and acetate plus ammonium amended columns were completely removed by the aquifer microorganisms by the column outlet. In ethanol-amended and soluble starch amended columns none of the nitrososubstituted metabolites were detected at the intermediate ports along the column length. In control columns low levels of MNX, DNX, and TNX were detected at intermediate sampling ports all along the column length. MNX was the most predominant transformation product identified at intermediate sampling ports in carbon amended treatment and carbon control columns. These results are similar to those reported by Bhushan et al. [31] that the disappearance of RDX was accompanied by the formation of MNX and ring cleavage product MDNA. However, in this study MDNA could not be detected because it is unstable in aqueous phase.

The rate of RDX biotransformation in the presence of different amendment mixture(s) was evaluated by fitting the steady-state advection-dispersion transport model with contaminant decay (Eq. (4)) to the axial RDX concentration profiles obtained in the bed profile test described above. Eq. (4) fits very well to RDX transformation data in the presence of different amendment mixture(s) obtained from the bed profile test (Fig. 8).

The first-order biodegradation rate coefficient for RDX biotransformation in presence of acetate ranged between 0.140 and $0.447 \mathrm{~h}^{-1}$ for acetate amended columns as compared to 0.037 to $0.083 \mathrm{~h}^{-1}$ in control columns where no carbon source was used. RDX biodegradation rate coefficients 

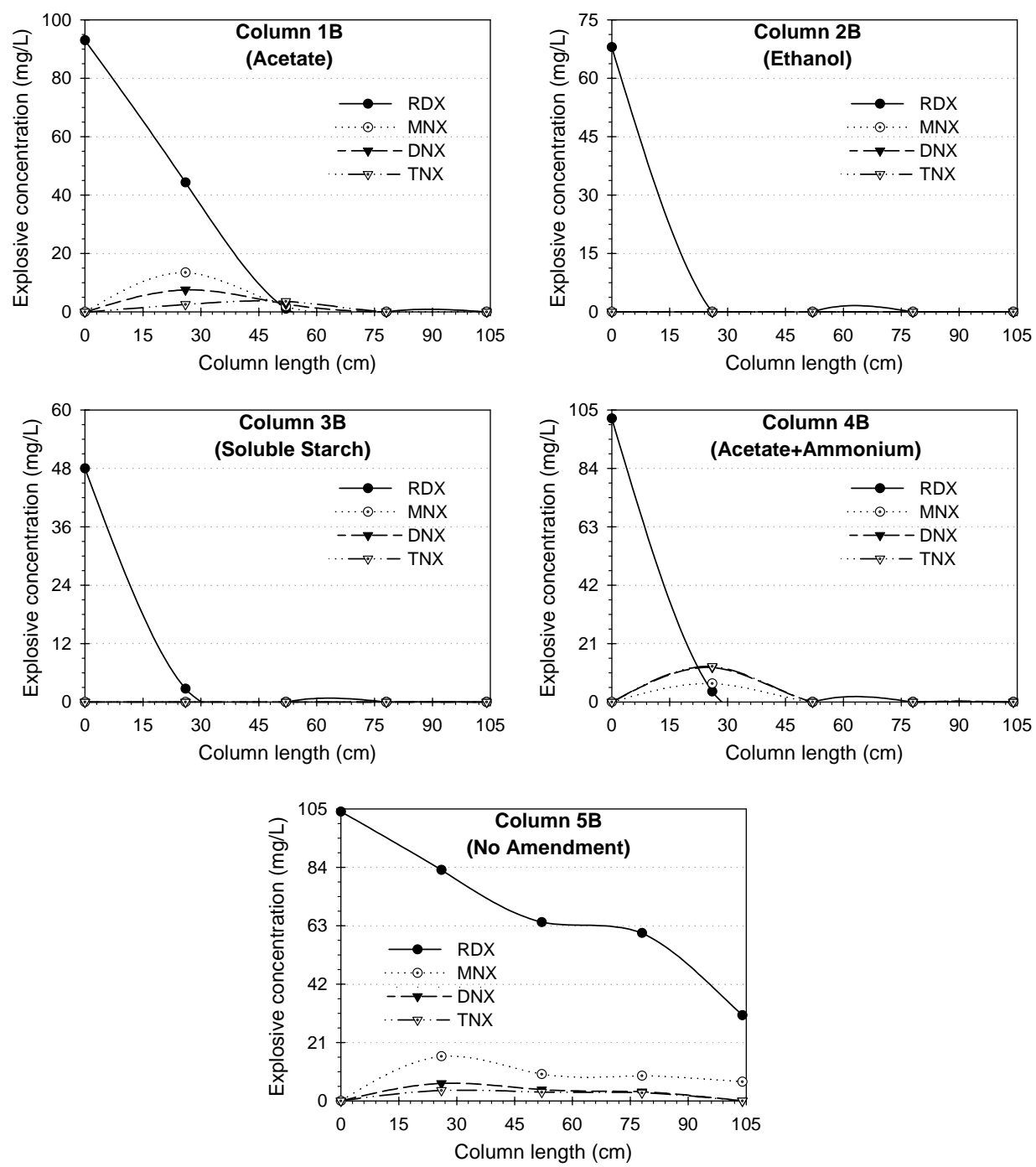

Fig. 7. Axial concentration profile of RDX and its transformation products along column length. Results of middle column from each triplicate set presented.

estimated from the bed profile test for individual columns are summarized in Table 2.

Of the three carbon sources tested, ethanol had a very significant (95\% confidence) effect in enhancing the reductive biotransformation of RDX. The rate of removal was so fast that there was not enough resolution to calculate the RDX rate kinetics in groundwater amended with ethanol. RDX removal rates in ethanol-amended columns were sig-

Table 2

Biodegradation rate kinetics of RDX in NOP aquifer material

\begin{tabular}{llllll}
\hline Column tag & \multicolumn{5}{l}{ RDX biodegradation rate coefficient, $k\left(\mathrm{~h}^{-1}\right)$} \\
\cline { 2 - 6 } & Acetate & Ethanol & Starch & $\begin{array}{l}\text { Acetate plus } \\
\text { ammonium }\end{array}$ & Control \\
\hline A & 0.256 & NC & 0.114 & 0.120 & 0.083 \\
B & 0.140 & NC & 0.433 & 0.267 & 0.037 \\
C & 0.447 & NC & NC & 0.336 & 0.061 \\
\hline
\end{tabular}

NC: not calculated due to low resolution of column profile (see Fig. 8). nificantly (95\% confidence) different than other columns amended with acetate and soluble starch. Removal rates were similar in the acetate amended and acetate plus ammonium amended columns. Addition of ammonium in groundwater amended with acetate did not have any significant $(95 \%$ confidence) effects on the enhancement of RDX degradation. These results are similar to those reported by Beller [16] under anaerobic conditions.

\subsection{Groundwater toxicity}

Groundwater toxicity, using Microtox ${ }^{\circledR}$ analysis, was performed on influent and effluent streams from individual columns. Results of Microtox ${ }^{\circledR}$ analyses on column influent and effluent are summarized in Table 3. Out of the three carbon sources used, ethanol showed acute toxic effects in effluent streams from ethanol-amended columns. This effluent toxicity in ethanol-amended columns probably was either as a result of conversion of ethanol to some toxic intermediate 

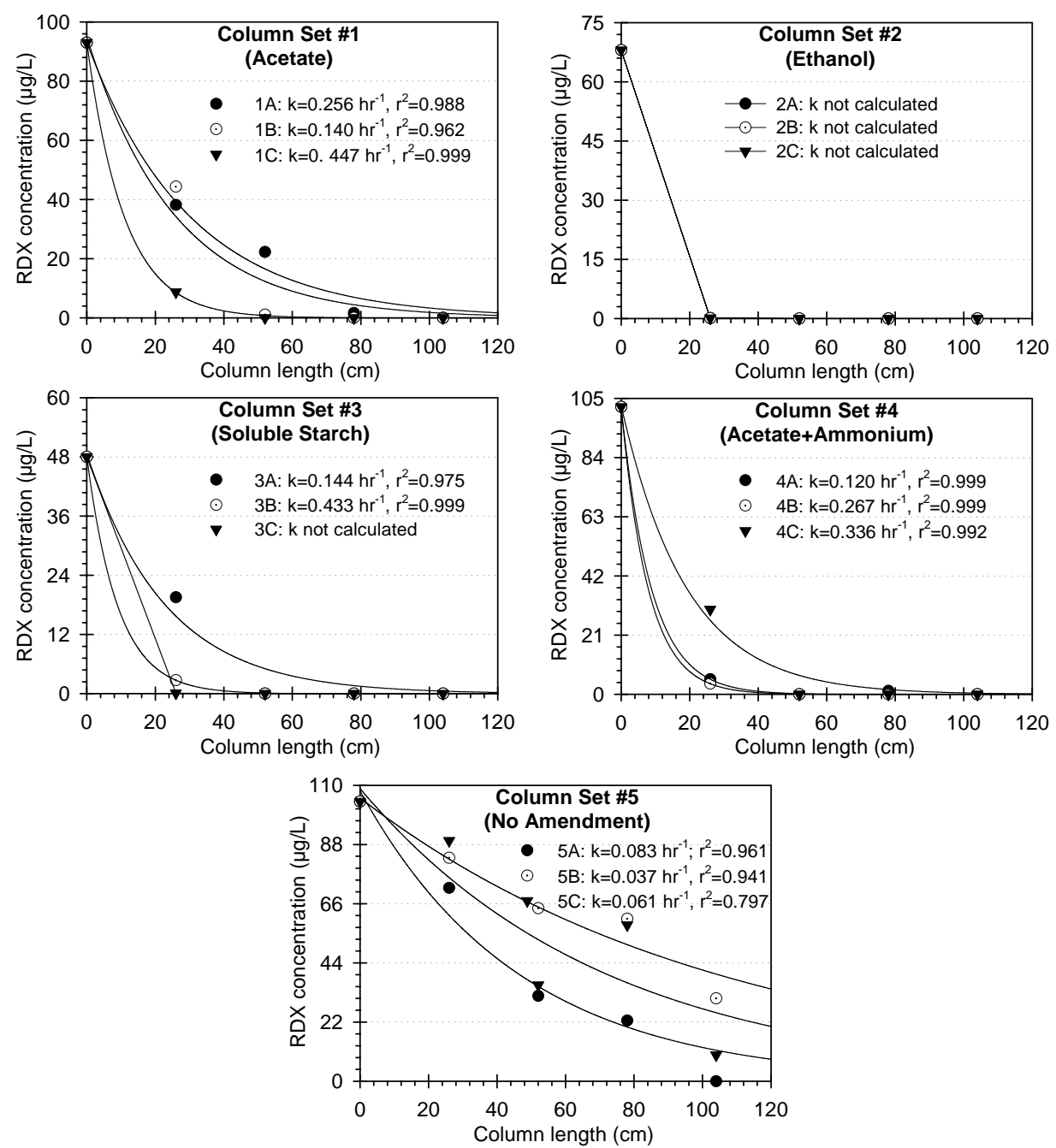

Fig. 8. RDX biodegradation kinetic analysis. Symbols and lines represent the actual data and model fit, respectively.

transformation product(s) in presence of RDX metabolites or interaction of ethanol with the RDX transformation products some of which are toxic. Soluble starch amendment exhibited toxicity in the influent stream that was partially removed in the soil column. Since some of the RDX was biodegraded in the inlet tanks as a result of reduced conditions, and the interaction of some of these RDX transformation products with soluble starch might have created toxicity in the influent stream. Presence of acetate in groundwater did not show any toxicity to the test microorganisms used in Microtox ${ }^{\circledR}$.

Table 3

Toxicity levels of influent and effluent from each column

\begin{tabular}{|c|c|c|c|c|c|c|}
\hline \multirow[t]{2}{*}{ Column tag } & \multirow[t]{2}{*}{ Time interval (min) } & \multicolumn{5}{|c|}{ Toxicity levels, $\mathrm{EC}_{50}(\%)$} \\
\hline & & Acetate & Ethanol & Starch & Acetate plus ammonium & Control \\
\hline Inlet tank & 5 & BDL & BDL & 24.96 & BDL & BDL \\
\hline Outlet-A & 5 & BDL & 9.58 & BDL & BDL & BDL \\
\hline Outlet-B & 5 & BDL & 7.11 & 36.78 & BDL & 84.54 \\
\hline Outlet-C & 5 & BDL & 7.11 & BDL & BDL & BDL \\
\hline Inlet tank & 15 & BDL & BDL & 13.69 & BDL & BDL \\
\hline Outlet-A & 15 & BDL & 9.32 & BDL & 24.24 & 64.06 \\
\hline Outlet-B & 15 & BDL & 7.43 & 29.24 & BDL & BDL \\
\hline Outlet-C & 15 & BDL & 7.24 & BDL & 78.59 & BDL \\
\hline
\end{tabular}

BDL: below detection limit. 


\section{Conclusions}

Influent RDX concentrations in groundwater were removed without the detection of any nitroso-transformation products in the column effluents from amendment treatment as well as amendment control columns. In the amendment control columns the RDX biodegradation was a manifestation of artificially reduced conditions created by pressurizing the feed groundwater with helium gas in the inlet reservoir. Out of the three carbon sources used acetate performed the best. Acetate amended columns not only achieved the highest RDX biodegradation rate coefficient, but also did not exhibit any toxicity in the influent or effluent stream. Furthermore, in ethanol-amended and soluble starch amended columns, biological activity converted ethanol and soluble starch into acetate for further utilization as an electron donor. Therefore, it seems acetate is the favored carbon source for the microorganisms involved in this study.

The treatability study demonstrated that in situ bioremediation of RDX can be achieved by inducing a reductive environment using readily available carbon source. The phenomenon of artificially created reducing conditions encountered in amendment control columns need to be addressed in designing the field demonstration. Moreover field activities will involve the competition for electrons from additional oxidants (dissolved oxygen), and other inorganic electron acceptors (nitrate, and sulfate) in the aquifer. Low redox conditions can be achieved by providing sufficient quantities of a readily biodegradable carbon source. Furthermore, to avoid the accumulation of nitroso-substituted metabolites, and achieve the complete transformation of RDX and its nitroso derivatives a very low redox environment is needed.

\section{Acknowledgements}

Authors are grateful to the DoD's Environmental Security Technology Certification Program (ESTCP) for funding this research. Chemical analyses were performed by the Environmental Chemistry Branch of ERDC, and analytical assistance of Ms. Anne Weathersby is highly appreciated. Technical assistance provided by Dr. Terry Thonen, and Ms. Lisa Travelin of URS Greiner Woodward Clyde, Overland Park, MO in aquifer material and groundwater sampling is highly acknowledged. We gratefully acknowledge the assistance of Mr. Al Kam (CHAAP site manager) and Mr. Tom Graff (NOP site manager) that was necessary for the completion of the sampling effort. We are thankful to Mr. Jeff Breckenridge, US Army Corp of Engineers-Center of Expertise, for his help and assistance in the collection of site data nationwide.

\section{References}

[1] J. Akhavan, The Chemistry of Explosives, Royal Society of Chemistry, Cambridge, UK, 1998.
[2] J.C. Pennington, in: W.C. Anderson, R.C. Loehr, B.P. Smith (Eds.), Environmental Availability in Soils: Chlorinated Organics, Explosives, Metals, Am. Acad. Environ. Eng., New York, 1999, p. 85.

[3] DENIX (Defense Environmental Network and Information Exchange), Enhanced Alternative and In Situ Treatment Technologies for Explosives in Groundwater, 2003. http://www.denix.osd.mil/ denix/DOD/Policy/Army/Aerta/Report/a12a.html.

[4] N.G. McCormick, J.H. Cornell, A.M. Kaplan, Appl. Environ. Microbiol. 42 (1981) 817.

[5] T.W. Sheremata, A. Halasz, L. Paquet, S. Thiboutot, G. Ampleman, J. Hawari, Environ. Sci. Technol. 35 (2001) 1037.

[6] J. Singh, S.D. Comfort, L.S. Hundal, P.J. Shea, J. Environ. Qual. 27 (1998) 572.

[7] ATSDR, RDX Fact Sheet, 1996. http://www.atsdr.cdc.gov/tfacts78. html.

[8] US EPA, Drinking Water Standards and Health Advisories, Office of Water, EPA 822-R-02-038, 2002.

[9] A. Brenner, Z. Ronen, Y. Harel, A. Abeliovich, Water Environ. Res. 72 (2000) 469.

[10] N.V. Coleman, D.R. Nelson, T. Duxbury, Soil Biol. Biochem. 30 (1998) 1159.

[11] P.R. Binks, S. Nicklin, N.C. Bruce, Appl. Environ. Microbiol. 61 (1995) 1318.

[12] T.W. Sheremata, J. Hawari, Environ. Sci Technol. 34 (2000) 3384.

[13] P. Bayman, S.D. Ritchey, J.W. Bennett, J. Ind. Microbiol. 15 (1995) 418.

[14] T. Fernando, S.D. Aust, in: D.W. Tedder, F.G. Pohland (Eds.), Emerging Technologies in Hazardous Waste Management, Am. Chem. Soc., Washington, DC, 1991, p. 214.

[15] M.C. Morley, S.N. Shammas, G.E. Speitel Jr., Environ. Eng. Sci. 19 (2002) 237.

[16] H.R. Beller, Water Res. 36 (2002) 2533.

[17] J. Hawari, A. Halasz, T. Sheremata, S. Beaudet, C. Groom, L. Paquet, C. Rhofir, G. Ampleman, S. Thiboutot, Appl. Environ. Microbiol. 66 (2000) 2652.

[18] J. Hawari, S. Beaudet, A. Halasz, S. Thiboutot, G. Ampleman, Appl. Microbiol. Biotechnol. 54 (2000) 605.

[19] D.L. Freedman, K.W. Sutherland, Water Sci. Technol. 38 (1998) 33.

[20] D.M. Young, P.J. Unkefer, K.L. Ogden, Biotechnol. Bioeng. 53 (1997) 515.

[21] C.L. Kitts, D.P. Cunningham, P.J. Unkefer, Appl. Environ. Microbiol. 60 (1994) 4608.

[22] R.J. Spanggord, J.C. Spain, S.F. Nishino, K.E. Mortelmans, Appl. Environ. Microbiol. 57 (1991) 3200.

[23] J.E. Walker, D.L. Kaplan, Biodegradation 3 (1992) 369.

[24] A. Halasz, J. Spain, L. Paquet, C. Beaulieu, J. Hawari, Environ. Sci. Technol. 36 (2002) 633.

[25] H.C. Pitot III, Y.P. Dragan, in: C.D. Klaassen, J. Doull (Eds.), Casarett and Doull's Toxicology: The Basic Science of Poisons, 5th ed., McGraw Hill, New York, 1995, p. 201.

[26] S.B. Funk, D.J. Roberts, D.L. Crawford, R.L. Crawford, Appl. Environ. Microbiol. 59 (1993) 2171.

[27] M.Th. vanGenuchten, W.J. Alves, Analytical solutions of the onedimensional convective-dispersive solute transport equation, Technical Bulletin No. 1661, US Department of Agriculture, 1982.

[28] B.M. Das, Principles of Geotechnical Engineering, 3rd ed., PWS Publishing, Boston, 1994, p. 44.

[29] N.R. Adrian, A. Lowder, Biodegradation of RDX and HMX by methanogenic enrichment culture, in: Battelle Symposium Proceedings, vol. 5, No. 7, 1999, p. 1.

[30] B.-T. Oh, C.L. Just, P.J.J. Alvarez, Environ. Sci. Technol. 35 (2001) 4341.

[31] B. Bhushan, A. Halasz, J. Spain, S. Thiboutot, G. Ampleman, J. Hawari, Environ. Sci. Technol. 36 (2002) 3104. 